\title{
LARVAL DEVELOPMENT OF AUSTROPANDALUS GRAYI (CUNNINGHAM, 1871) (DECAPODA, CARIDEA, PANDALIDAE) FROM THE SOUTHWESTERN ATLANTIC OCEAN ${ }^{1}$ )
}

\author{
BY \\ SVEN THATJE ${ }^{2,4}$ ) and ROSA BACARDIT ${ }^{3}$ ) \\ ${ }^{2}$ ) Alfred Wegener Institute for Polar and Marine Research, P.O. Box 120 161, \\ D-27515 Bremerhaven, Germany \\ 3) Juana Azurduy 1611, 1424 Buenos Aires, Argentina
}

\begin{abstract}
Austropandalus grayi and Pandalopsis ampla are the only members of the Pandalidae recorded from coastal waters of Argentina. The identification of planktonic larvae of A. grayi from the southwestern Atlantic and the Magellan Region was confirmed by comparing stage I zoeae with larvae hatched in the laboratory. Zoeal stages I-V and an advanced larval stage were distinguished, and their morphology and distribution are described. The phylogenetic relations of pandalid larvae and the position of A. grayi in the family are discussed.
\end{abstract}

\section{RESUMEN}

Austropandalus grayi y Pandalopsis ampla son los únicos miembros de la familia Pandalidae citados en las aguas costeras de Argentina. La identificación de larvas planctónicas de A. grayi procedentes del Atlántico suroeste y de la región Magallánica, se ha confirmado comparando el estadío larvario Zoea I con el de larvas obtenidas en el laboratorio. Los estadíos larvarios Zoea I-V y un estadío larvario más desarrollado fueron también identificados, y su morfología y distribución descritos. Se discuten las relaciones filogenéticas de las larvas de pandálidos así como la posición de A. grayi dentro de la familia.

\section{INTRODUCTION}

Larval descriptions are essential to the understanding of life-history strategies, stock-recruitment, and general plankton ecology. In practice, ecological work on South American meroplankton communities, such as decapod larvae, are hardly

\footnotetext{
1) Alfred Wegener Institute publication No. 1625 .

$\left.{ }^{4}\right)$ e-mail: sthatje@awi-bremerhaven.de
} 
possible at generic and specific levels due to the lack of larval descriptions. This is especially true for Chilean and Argentinean waters, where autecological studies on decapod larvae are still scarce (e.g., Palma, 1994; Wehrtmann \& Báez, 1997; Albornoz \& Wehrtmann, 1997).

The first larval descriptions of Argentinean and Chilean decapods were published in the first half of this century (Schwabe, 1936; Gurney, 1937). Most publications were produced between 1967 and 1978 (e.g., Boschi et al., 1967; Boschi \& Scelzo, 1977; Kurata, 1968; Scelzo \& Lichtschein, 1978), followed by a period with fewer publications, finally resulting in a pause between 1987 and 1995 (see also Wehrtmann \& Báez, 1997). At the moment, the number of larval descriptions is slowly increasing again (e.g., Wehrtmann \& Albornoz, 1998; Albornoz \& Wehrtmann, 1997; Thatje \& Bacardit, 2000; Thatje et al., in press).

The present study provides detailed descriptions of the planktonic larval stages of the pandalid prawn Austropandalus grayi (Cunningham, 1871). This species is known to be widely distributed on the Chilean and Argentinean coasts (Retamal, 1981; Spivak, 1997; Gorny, 2000). A. grayi is the only representative of this genus known to inhabit the channels and fjords of the Magellan Region (see Gorny, 2000), and only one more pandalid species (Pandalopsis ampla Bate, 1888) is known to occur in the southwestern Atlantic Ocean (Boschi, 1976; Spivak, 1997). Comparisons of laboratory-reared first zoeae with field-collected larvae, as well as a comparison of plankton material from the Magellan Region and the southwestern Atlantic, allow unambiguous identification of the species studied.

\section{MATERIAL AND METHODS}

The present study provides the first descriptions of the larval stages of A. grayi from the southwestern Atlantic Ocean. The material studied was collected in 1978, 1979, and 1982 by the German vessel "Walther Herwig" during cruises III/1 (5th leg) and III/2 (6th leg), RVs "Shinkai Maru" and "Dr. E. L. Holmberg", respectively, carried out on the Argentinean shelf and continental slope in the southwestern Atlantic (Ciechomski et al., 1979; Cousseau et al., 1979). Samples were collected by means of a Bongo net of $330 \mu \mathrm{m}$ mesh size and were preserved in $3 \%$ formalin solution buffered with hexamethylenetetramine. Complete description s of the cruises and additional information on oceanographic measurements can be obtained from Ciechomski et al. (1979).

The larval material obtained during these cruises has been compared with material collected with a plankton net of $200 \mu \mathrm{m}$ mesh size in monthly sampling from an inflatable dinghy in the Beagle Channel (Magellan Region, Tierra del 
Fuego) from 1987 to 1989 (see: Lovrich, 2000). Additionally, first zoeae were obtained from egg-carrying females which were held in the laboratory, thus allowing a certain identification of the species. In addition, we studied eggs and prezoeae obtained from egg-carrying females of Pandalopsis ampla from the INIDEP collection, Buenos Aires, Argentina (Instituto Nacional de Investigación y Desarrollo Pesquero, Reg. Nos. 1734, 1740, 1748, and 1803).

Carapace length (LC) was measured from the posterior edge of the orbital arch to the mid-dorsal posterior margin of the carapace; total lengths (LT) of the larvae were measured from the base of the rostrum, between the eyes, to the distal margin of the telson, excluding setae. Nomenclature used for the differentiation of the larval phases and the larval morphology corresponds to that suggested by Williamson (1960, 1968, 1982), Gurney (1942), Boschi (1981), and Haynes (1978, 1981, 1985).

RESULTS

Austropandalus grayi (Cunningham, 1871)

Zoea I (fig. 1A-L)

$\mathrm{LT}=2.9 \mathrm{~mm} ; \mathrm{LC}=0.9 \mathrm{~mm} ; N=15$.

General characteristics: eyes sessile; rostrum acute, slightly curved downward; anterior ventral margin with a pair of pronounced pterygostomian spines, and one pair of reduced anteroventral spines (fig. 1A, C); two dorsal protuberances; carapace with anterior and posterior papillae (fig. 1C).

Antennule: peduncle unsegmented with an inner plumose seta; outer flagellum unsegmented with 4 aesthetascs and a plumose seta (fig. 1E).

Antenna: exopodite segmented, no terminal spine; one subterminal seta on outer margin; distal inner margin (including tip) with 9 setae; endopodite with 2 terminal processes, inner one articulating at base; ventral inner spine well developed, as long as endopodite (excluding terminal processes), bearing small spines (fig. 1F).

Mandible: incisor process sharp, with strong denticles; molar process with small denticles and protuberances bearing denticles, palp absent (fig. 1D).

Maxillule: coxal endite with 6 setae; basal endite with two pronounced spiny protuberances and 3 thinner setae; palp with indication of segmentation, with 3 apical and 2 subterminal setae; one large plumose seta on outer lobe (fig. 1H).

Maxilla: coxal endite with 9 setae; distal endite with 4 setae; basal endites with 4 setae each; palp with 3, 2, 1, 1, 2 setae; scaphognathite with 4 marginal plumose setae and a terminal flagellum (fig. 1G). 


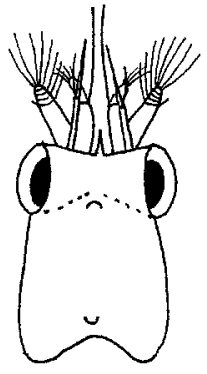

A

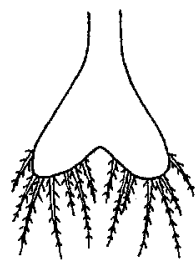

B

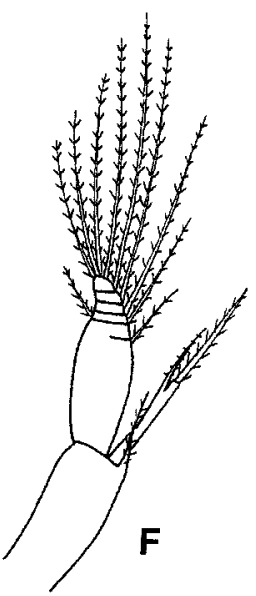

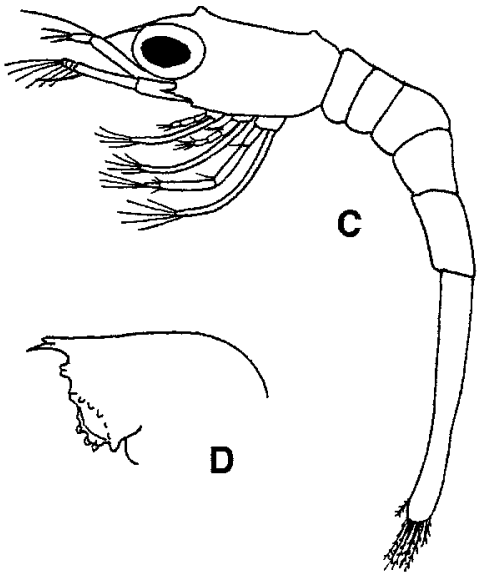
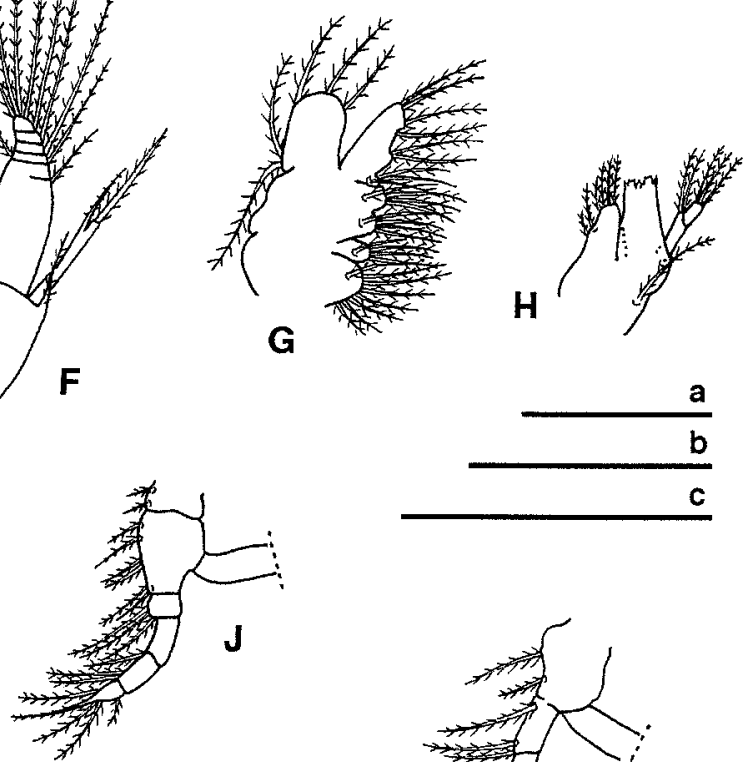

C
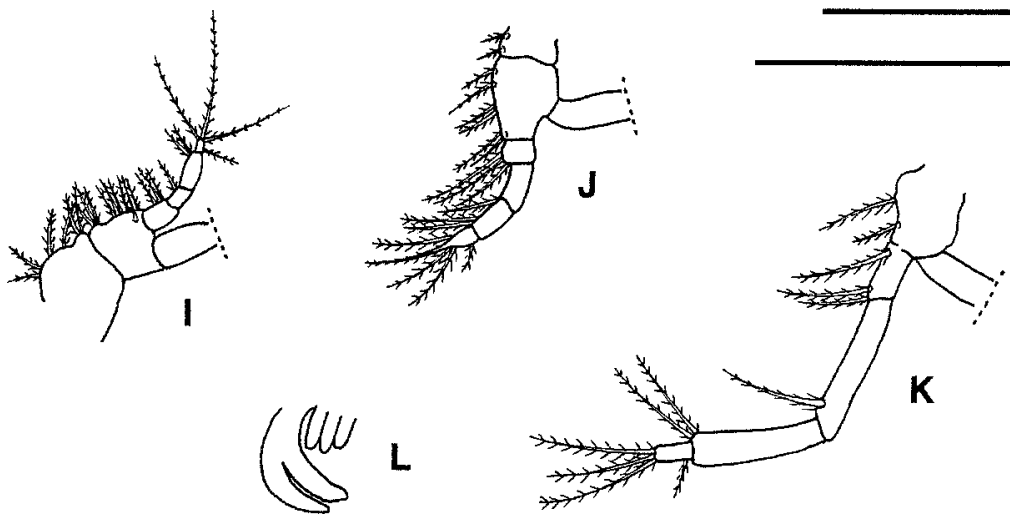

Fig. 1. Austropandalus grayi (Cunningham, 1871), first zoeal stage. A, carapace, dorsal view; B, telson, dorsal view; C, zoea I, lateral view; D, mandible; E, antennule; F, antenna; G, maxilla; $\mathrm{H}$, maxillule; I, maxilliped 1; J, maxilliped 2; K, maxilliped 3; L, pereiopods, lateral view. Scale bars: a (D, G-H), $0.2 \mathrm{~mm}$; b (A-C), $1 \mathrm{~mm}$; c (E-F, I-L), $0.5 \mathrm{~mm}$. 
Maxilliped 1: coxa with 6 setae; basis of 3 groups of 3 setae each; endopodite of 4 segments with 3,1,2, 3+ 1 setae; exopodite with 3 apical and 1 subterminal setae (fig. 1I).

Maxilliped 2: coxa with 2 setae; basipodite with 1, 1, 2, 2 setae; endopodite of 4 segments with $3,1,2,3+1$ setae; dactylus bearing a strong terminal spine; exopodite with 3 apical and 2 subterminal setae (fig. 1J).

Maxilliped 3: basis with 4 setae; endopodite of 4 segments with 2, 1, 2, 3+1 setae; exopodite with 3 apical and 2 subterminal setae (fig. 1K).

Pereiopods: reduced, first biramous; pereiopods 2-5 uniramous, rudimentary (fig. 1L).

Abdomen: somites without lateral spines; somite 6 fused with telson; pleopods absent (fig. 1C).

Telson: bilobed with strong median indentation; posterior margin with $7+7$ processes (fig. 1B).

\section{Zoea II (fig. 2A-H)}

$\mathrm{LT}=3.68 \mathrm{~mm} ; \mathrm{LC}=1.04 \mathrm{~mm} ; N=13$.

General characteristics: eyes pedunculate; carapace with supraorbital spines, well developed; anterior ventral margin bearing one pair of pterygostomian spines and 3 reduced anteroventral spines (fig. 2A, B).

Antennule: peduncle unsegmented, with one distal inner plumose seta and 2 setae at base of outer flagellum; the latter with 6 aesthetascs and a seta (fig. 1F).

Antenna: exopodite segmented, without terminal spine, one medial and subterminal setae at outer margin; distal inner margin (including tip) with 10 setae; terminal processes of endopodite more reduced than in previous stage (fig. 2E).

Mandible: without palp; no other differences.

Maxillule: coxal endite with 6 setae; basal endite with 5 strong spines without and 2 smaller ones with articulation (fig. $2 \mathrm{H}$ ).

Maxilla: coxal proximal endite with 11 setae; distal endite with 4 setae; scaphognathite with 4 marginal plumose setae and a terminal flagellum; no other differences (fig. 2G).

Maxilliped 1: endopodite of 4 segments; exopodite with 5 plumose setae; basis and endopodite unchanged.

Maxilliped 2: basis with 1, 2, 3, 3 setae; endopodite of 5 segments, carpus without setae; exopodite with 3 pairs +1 plumose setae; no other differences.

Maxilliped 3: endopodite of 5 segments, carpus without setae; exopodite with 8 plumose setae.

Pereiopods: 1-3 biramous; 4-5 uniramous, rudimentary (fig. 2D).

Abdomen: the same as in Zoea I.

Telson: with $8+8$ processes on posterior margin (fig. $2 \mathrm{C}$ ). 


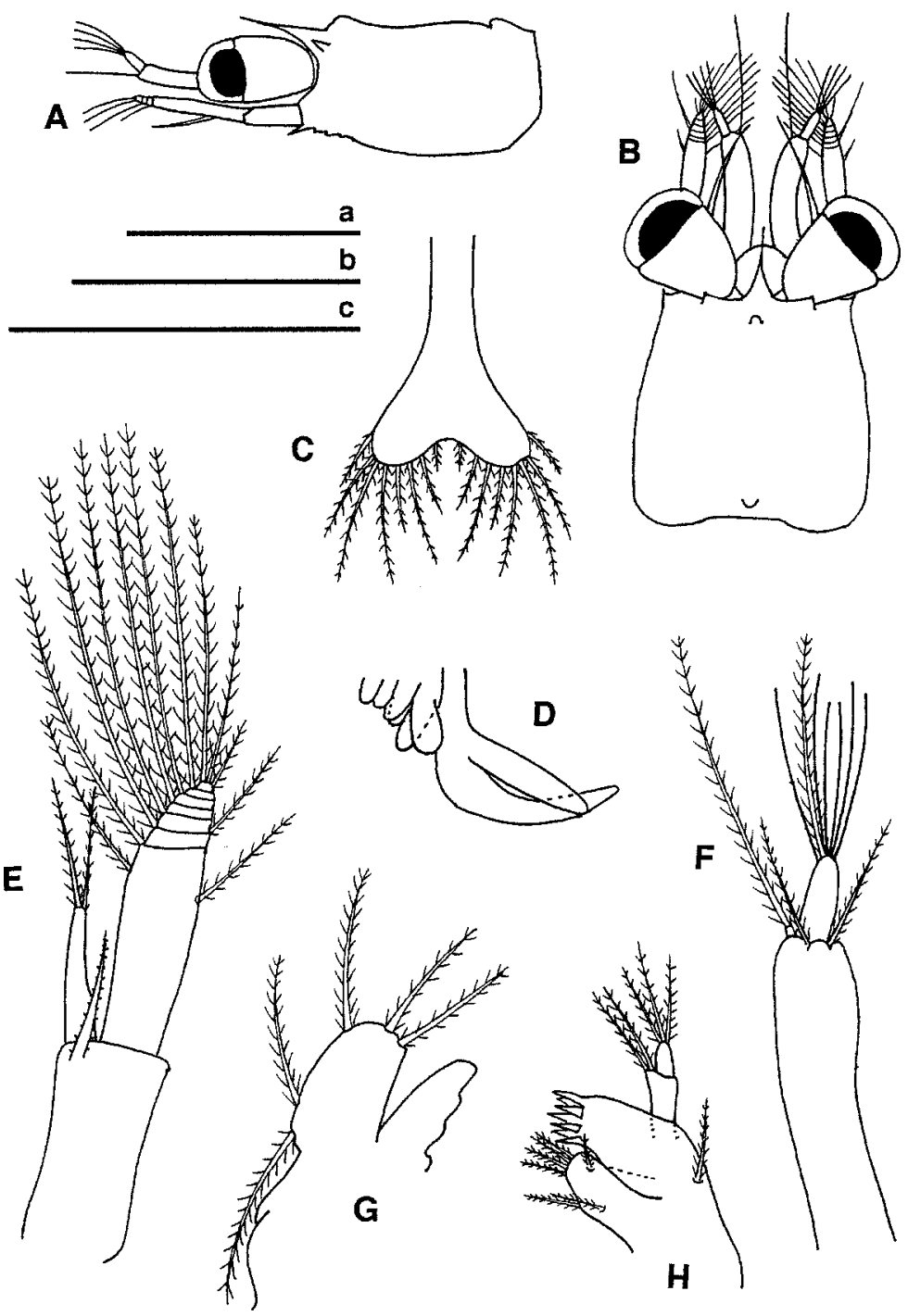

Fig. 2. Austropandalus grayi (Cunningham, 1871), second zoeal stage. A, carapace and cephalic appendages, lateral view; B, carapace, dorsal view; C, telson, dorsal view; D, pereiopods, ventral view; E, antenna; F, antennule; G, maxilla, scaphognathite; H, maxillule. Scale bars: a (G-H), $0.2 \mathrm{~mm}$; b (A-C), $1 \mathrm{~mm}$; c (D-F), $0.5 \mathrm{~mm}$.

\section{Zoea III (fig. 3A-H)}

$\mathrm{LT}=3.9 \mathrm{~mm} ; \mathrm{LC}=1.1 \mathrm{~mm} ; N=15$.

General characteristics: eyes pedunculate and prominent, well developed; carapace with better developed supraorbital spines than in previous stage; dorsal anterior protuberances curved posteriorly (fig. 3A, B). 


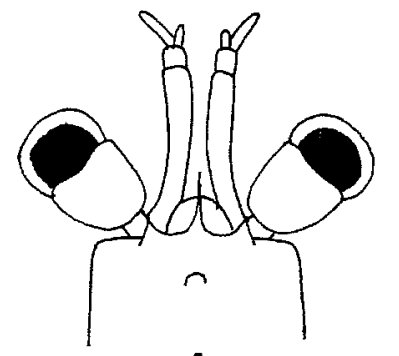

A

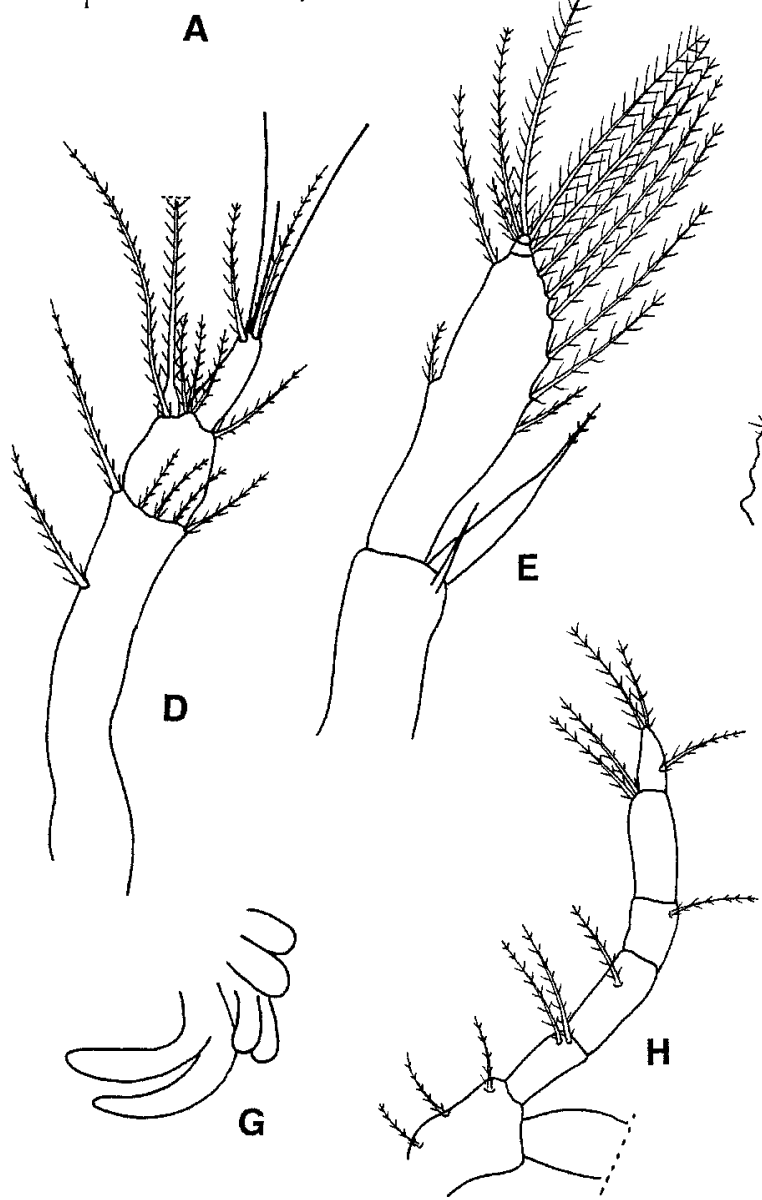

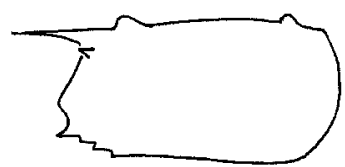

B
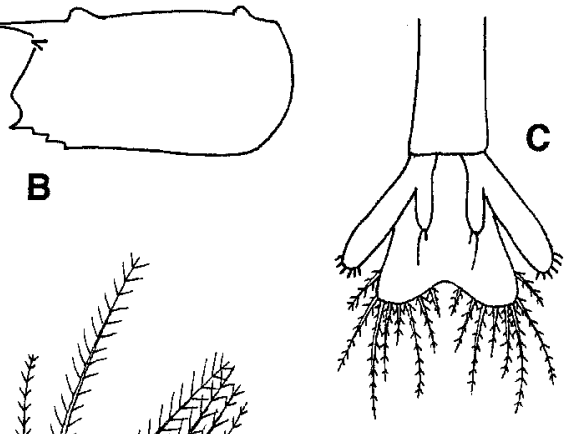
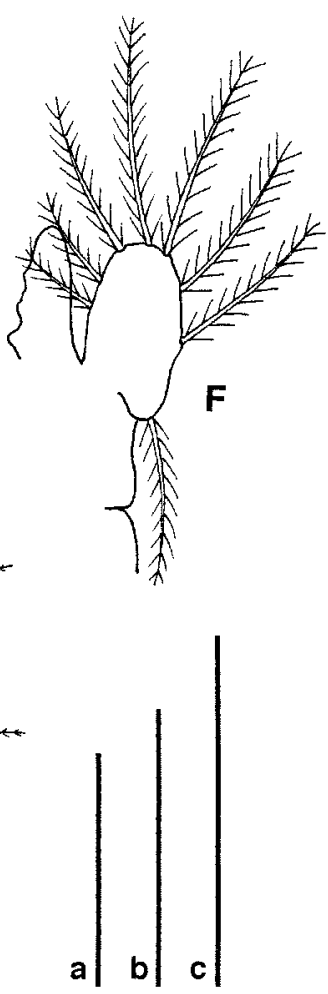

Fig. 3. Austropandalus grayi (Cunningham, 1871), third zoeal stage. A, anterior part of carapace and cephalic appendages, dorsal view; B, carapace, lateral view; C, uropods and telson, dorsal view; D, antennule; E, antenna; F, maxilla, scaphognathite; G, pereiopods 2-5, lateral view; $\mathrm{H}$, pereiopod 1, lateral view. Scale bars: a (F), $0.2 \mathrm{~mm}$; b (A-C), $1 \mathrm{~mm}$; c (D-E, G-H), $0.5 \mathrm{~mm}$.

Antennule: peduncle bisegmented; basal segment distally with 4 outer and 2 inner setae, one marginal, one distal; distal segment with outer and 1 large inner setae; medial distal lobe with 3 setae; outer flagellum with 3 aesthetascs and 2 setae; inner flagellum with 1 apical seta (fig. 3D). 
Antenna: exopodite dominant, with 2 marginal outer setae; inner margin (including tip) with 11 setae; apical segmentation reduced, short, without outer spine; endopodite with 1 less differentiated apical spine at base; basal inner spine reduced compared to previous stage (fig. 3E).

Mandible: without palp; no other differences.

Maxillule: coxal endite with 7 setae; basal endite with 8 spines, 3 of which are broadened at base; no other differences.

Maxilla: coxal endites with 12 and 5 setae, respectively; basal endites with 5 setae each; scaphognathite with 9 marginal setae (fig. 3F).

Maxilliped 1: coxa with 1, 2, 3, 1 setae; basis with 2, 4, 4, 3 setae; exopodite with 2 pairs of distal setae and 1 subterminal seta; no other differences.

Maxilliped 2: endopodite of 5 segments; carpus with 1 inner seta; exopodite with 3 pairs +1 plumose setae.

Maxilliped 3: endopodite of 5 segments with 1 outer seta on carpus; exopodite with 8 setae.

Pereiopod 1: basis with 3 setae; endopodite of 5 segments with 2, 1, 1, 2, 3 setae; exopodite with 8 setae (fig. $3 \mathrm{H}$ ).

Pereiopods 2 and 3: biramous, rudimentary (fig. 3G).

Pereiopods 4 and 5: uniramous, rudimentary (fig. 3G).

Abdomen: somites without spines and ornamentation; somite 6 free, not continuous with telson; no pleopods (fig. 3C).

Uropods: endopod of uropod with 2 apical setae, exopod twice as long as the inner, with 6 stout marginal setae (fig. 3C).

Telson: similar to previous stage, but lateral borders more parallel and median indentation less pronounced (fig. 3C).

\section{Zoea IV (fig. 4A-F)}

$$
\mathrm{LT}=4.98 \mathrm{~mm} ; \mathrm{LC}=1.28 \mathrm{~mm} ; N=12 \text {. }
$$

General characteristics: eyes pedunculate and prominent, developed; carapace with well-developed antennal spines; dorsal anterior protuberances curved anteriorly; supraorbital spine pronounced, as long as pterygostomian spine; three sharp anteroventral spines present (fig. 4A, B).

Antennule: trisegmented peduncle with incomplete segmentation between basal and medial segments; basal segment with strong spine and one subdistal inner spine; 3 outer distal setae and one inner seta; medial segment with 3 outer distal setae and one inner subdistal seta; distal segment with 2 inner setae; medial lobe with 4 setae; inner flagellum with one large, unsegmented apical seta; outer flagellum with 3 aesthetascs and 2 distal setae, unsegmented (fig. 4D).

Antenna: endopod unsegmented; with one strong outer spine, without inner setae; inner margin of exopod (including tip) with 16 marginal setae; endopodite 

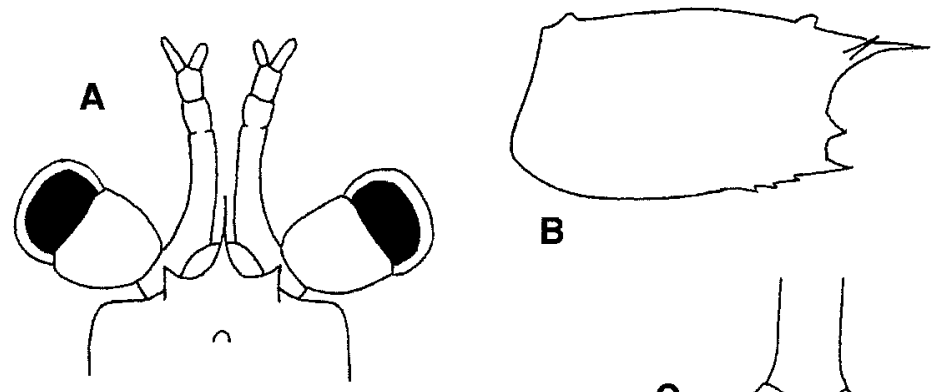

B

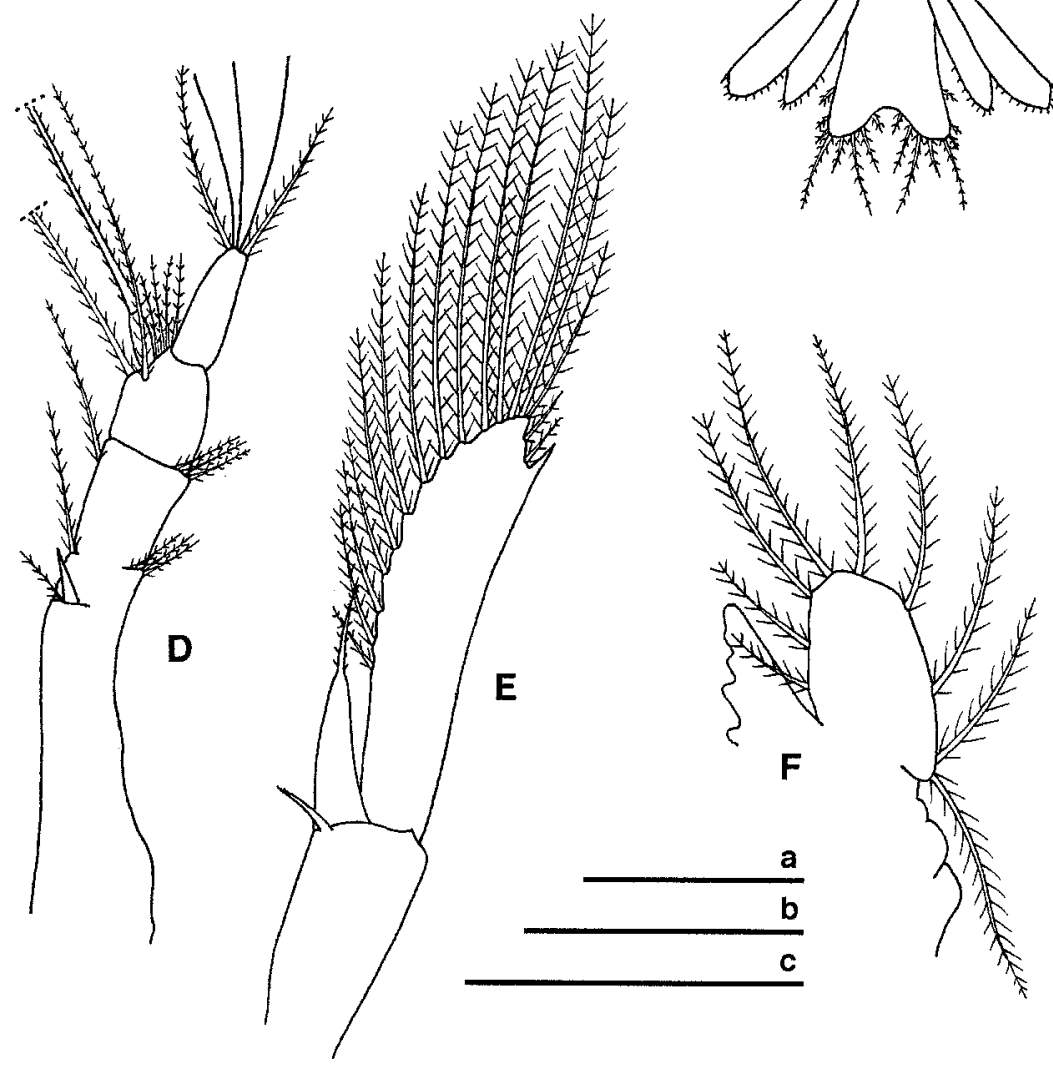

Fig. 4. Austropandalus grayi (Cunningham, 1871), fourth zoeal stage. A, anterior part of carapace and cephalic appendages, dorsal view; B, carapace, lateral view; C, uropods and telson, dorsal view; D, antennule; E, antenna; F, maxilla, scaphognathite. Scale bars: a (F), $0.2 \mathrm{~mm}$; b (A-C), $1 \mathrm{~mm}$; c (D-E), $0.5 \mathrm{~mm}$.

proportionally reduced with respect to previous stage; ventral inner spine reduced; ventral outer spine present as small protuberance (fig. 4E).

Mandible: without palp; no other differences. 
Maxillule: coxal endite with 7 setae; basal endite with 8 spines; no other differences.

Maxilla: proximal and distal coxal endites with 13 and 4 setae, respectively; basal endites with 5 setae each; scaphognathite with 10 marginal setae (fig. 4F).

Maxilliped 1: basis with 3, 4, 4, 4 setae; no other differences.

Maxilliped 2: exopodite with 8 plumose setae; no other differences.

Maxilliped 3: endopodite of 5 segments, carpus with one outer seta, shorter than in previous stage; exopodite with 8 setae.

Pereiopods 1 to 5: same as in previous stage.

Abdomen: somite 6 with short anal spine (fig. 4C).

Uropods: endopod with 9 marginal setae; exopod with one outer spine and 10 marginal setae (fig. 4C).

Telson: lateral margins almost parallel; posterior processes more reduced than in previous stage (fig. 4C).

\section{Zoea V (fig. 5A-I)}

$\mathrm{LT}=5.44 \mathrm{~mm} ; \mathrm{LC}=1.38 \mathrm{~mm} ; N=10$.

General characteristics: eyes pedunculate and extended laterally; carapace with large supraorbital spines, better developed than in previous stage; one medial dorsal spine between dorsal anterior protuberances at rostral base; anterior papillae more pronounced than in previous stages and larger than posterior one (fig. 5A, B).

Antennule: trisegmented peduncle with incomplete division between basal and distal segments; basal segment with prominent submedial spine, 2 inner setae and 4 distal outer spines; medial segment with 3 distal outer setae and 2 distal inner ones; distal segment with 2 marginal inner setae; distal lobe with 4 setae; inner flagellum with an apical seta; outer flagellum with 5 aesthetascs and 2 setae, 2 of those aesthetascs in subterminal position (fig. 5D).

Antenna: exopodite with strong outer spine, inner margin (including tip) with 18 setae; endopodite bisegmented with one small apical spine at distal segment; inner and outer basal spines present, inner less developed than in previous stage (fig. 5E).

Mandible: without palp.

Maxillule: coxal endite with 12 setae; basal endite with 9 spines, 3 of which are very fine, outer setae reduced; no other differences.

Maxilla: proximal and distal coxal endites with 14 and 4 setae, respectively; basal endites with 8 setae each; scaphognathite with 20 marginal setae (fig. 5F).

Maxilliped 1: coxa with 2, 2, 3, 2 setae; basis with 3, 5, 5, 5 setae; no other differences compared to previous stage.

Maxilliped 2: basis with 1, 2, 3, 3 setae; endopodite of 5 segments, carpus with one inner and outer seta; exopodite unchanged to previous stage; no other differences. 

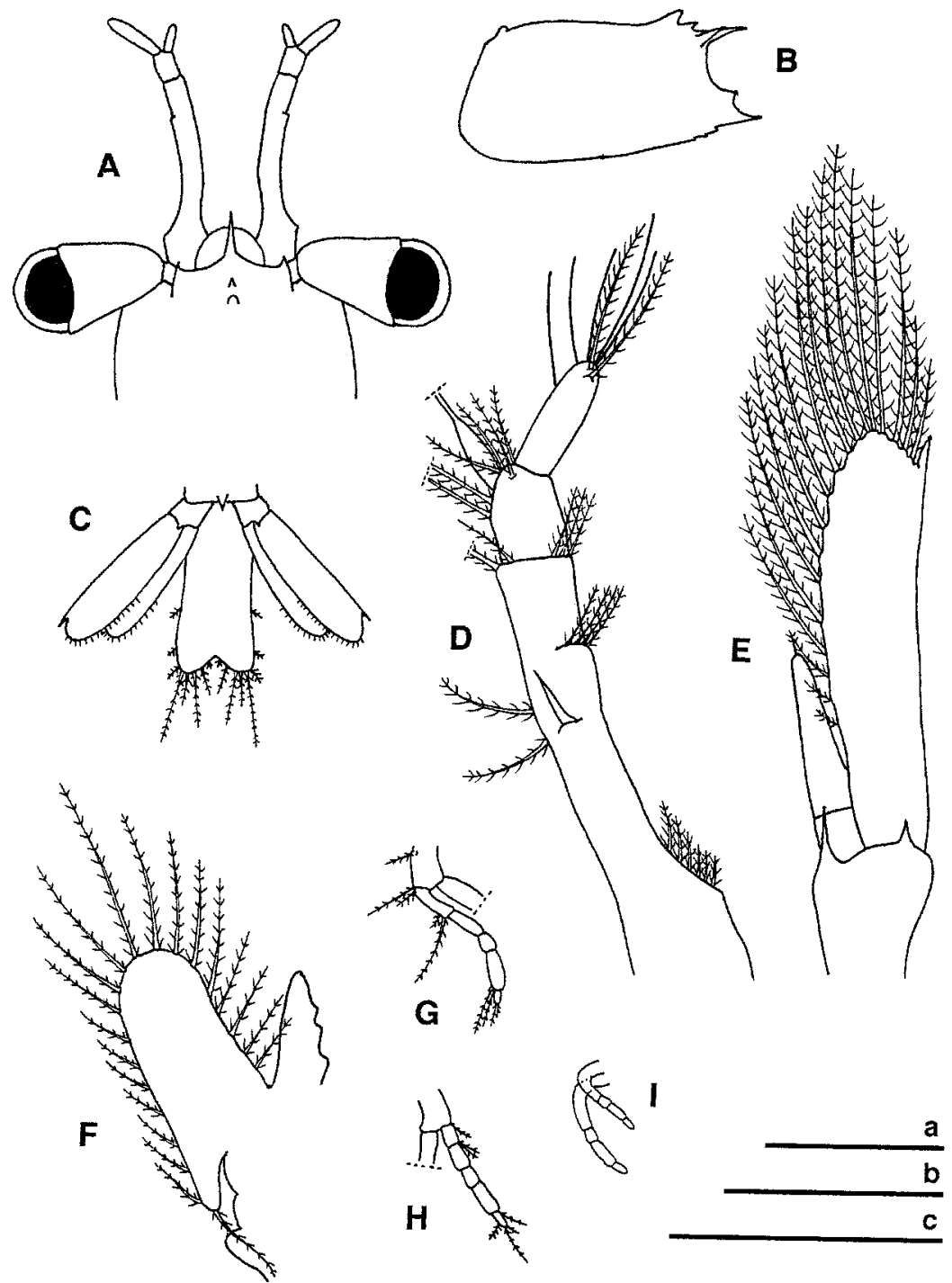

Fig. 5. Austropandalus grayi (Cunningham, 1871), fifth zoeal stage. A, anterior part of carapace and cephalic appendages, dorsal view; B, carapace, lateral view; C, uropods and telson, dorsal view; D, antennule; E, antenna; F, maxilla, scaphognathite; G, pereiopod 2, lateral view; H, pereiopod 3, lateral view; I, pereiopod 4 ( 5 the same), lateral view. Scale bars: a (F), $0.2 \mathrm{~mm}$; b (A-C, G-I), $1 \mathrm{~mm}$; c (D-E), $0.5 \mathrm{~mm}$.

Maxilliped 3: exopodite with 4 pairs of setae and 2 unpaired outer ones.

Pereiopod 1: exopodite with 5 pairs of setae and one unpaired outer one; same as in previous stage.

Pereiopod 2: coxa with 3 setae; endopodite of 5 segments with 2, 0, 0, 2, 2 setae; exopodite with 5 pairs of setae and one unpaired outer one (fig. 5G). 
Pereiopods 4 and 5: uniramous, endopodite of 4 segments, without setae; basis and endopodite unsegmented (fig. 5I).

Abdomen: same as in previous stage, anal spine of somite 6 more developed (fig. 5C).

Uropods: exopod with one strong outer spine and 17 marginal setae; endopod with 12 marginal setae (fig. 5C).

Telson: lateral margins parallel, with 3 marginal setae each; posterior margin with $5+5$ processes; medial indentation less pronounced (fig. 5C).

Advanced zoea (fig. 6A-L)

$\mathrm{LT}=9 \mathrm{~mm} ; \mathrm{LC}=2.66 \mathrm{~mm} ; N=8$.

General characteristics: rostrum straight, with 5 dorsal spines, curved, directed anteriorly; with posterior papillae; supraorbital spines broadened at base; 2 dorsal protuberances (fig. 6B).

Antennule: peduncle of 4 segments; basal segment with one subterminal inner seta, one strong medial distal spine, stylocerite with 6 setae and one proximal broad protuberance bearing an outer spine; medial segment proximally with 4 marginal inner setae and 8 distal ones, one outer seta; medial distal segment with 3 marginal inner and 6 distal setae; distal segment with 4 large setae at base of distal lobe and 2 outer ones; inner flagellum with large seta, unsegmented; outer flagellum bisegmented, basal segment with 4 groups of 3 aesthetascs each; distal segment with 3 subterminal aesthetascs and 2 apical setae (fig. 6E).

Antenna: exopodite with strong external spine, and stouter than in previous stage; internal margin (including tip) with 39 setae; endopodite bisegmented and prominent, bearing 4 short inner setae; basal segment with an distal inner seta; ventral outer spine well-developed; lobe with short distal seta next to ventral internal spine (fig. 6C).

Maxillule: coxal endite with 19 setae, 5 of which spinulose; basal endite with 14 spines and 10 setae, without outer seta; no other differences.

Maxilla: coxal endites with 19 and 4 setae, respectively; basal endites with 12 setae each; scaphognathite with 50 to 53 marginal setae (fig. 6D).

Mandible: without palp, no other differences.

Maxilliped 1: coxa with 3, 3, 4, 2 setae; basis with 26 marginal setae; endopodite with 5, 2, 2, 4 setae; endopodite with 10 plumose setae; no other differences.

Maxilliped 2: basis with 1, 1, 1, 4, 3 setae; ischium, merus, and carpus with 3/1, 2/1, 1/1 setae, respectively; carpus with marginal inner seta, 3 distal outer setae and 2 marginal outer ones; dactylus with 6 apical setae and a strong spine; exopodite with 14 plumose setae; no other differences.

Maxilliped 3: basis with 1, 3, 2 setae; ischium with 2 distal and a subdistal inner setae; merus with 3 marginal inner and 1 distal outer setae; carpus with 1 inner 

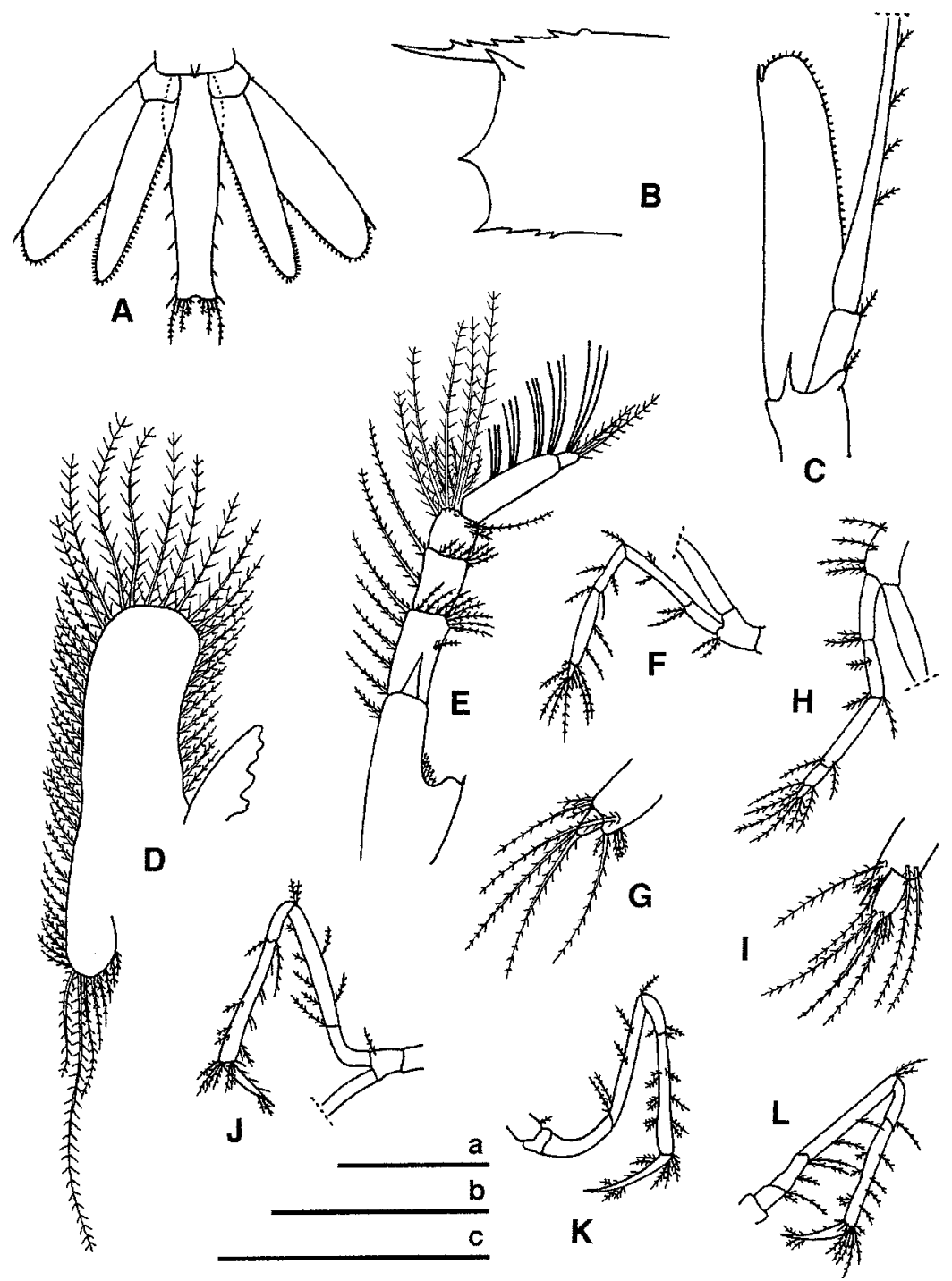

Fig. 6. Austropandalus grayi (Cunningham, 1871), advanced zoeal stage. A, uropods and telson, ventral view; B, carapace, lateral view; C, antenna; D, maxilla, scaphognathite; E, antennule; F, pereiopod 1, lateral view; G, endopodite of pereiopod 1; H, pereiopod 2, lateral view; I, endopodite of pereiopod 2; J, pereiopod 3, lateral view; K, pereiopod 4, lateral view; L, pereiopod 5, lateral view.

Scale bars: a (A, F, H, J-L), $1 \mathrm{~mm}$; b (B-C, E), $1 \mathrm{~mm}$; c (D, G, I), $0.5 \mathrm{~mm}$.

and 2 outer setae; propodus with 11 marginal inner setae and 2 distal inner spines, 2 marginal and 3 outer distal setae; dactylus with 3 apical and 1 subapical setae; exopodite with 16 plumose setae. 
Pereiopod 1: basis with 2 setae; endopodite of 5 segments with 2, 5, and 4 setae on segments 1-3; propodus with 2 marginal inner spines, 2 distal inner spines and 5 setae; exopodite with 20 plumose setae (fig. 6G).

Pereiopod 2: basis with 4 setae; ischium, merus, and carpus with 2, 3, 2 setae, respectively; propodus with 1 distal outer spine and one seta, finger with 2 large proximal setae, 3 subdistal ones and a short terminal spine; dactylus with large terminal spine and 2 large and 1 short setae; exopodite with 20 plumose setae (fig. 6H).

Pereiopod 3: basis with 1 seta; ischium, merus and carpus with 1, 8, and 2 setae, respectively; propodus with 4 marginal inner spines and 3 setae, 2 distal inner spines and 2 setae; 3 marginal outer setae and 4 distal inner ones; dactylus with 3 marginal inner spines and 2 subapical setae; exopodite with 18 plumose setae (fig. 6J).

Pereiopod 4: endopodite of 5 segments; ischium, merus, and carpus with 2, 3, 3 setae, respectively; propodus with 3 marginal spines and 3 inner setae, 2 distal inner setae, 4 marginal and 4 distal outer setae; dactylus with 3 spines and 1 seta at inner margin and 2 distal subapical outer setae; uniramous (fig. 6K).

Pereiopod 5: endopodite of 5 segments; ischium, merus, and carpus with 3, 4, 1 setae, respectively; propodus with 3 spines and 2 marginal inner setae, 2 spines and 1 distal inner seta, 5 marginal and 6 distal outer setae; dactylus with 3 spines and 1 inner seta, 2 subdistal outer setae; uniramous (fig. 6L).

Abdomen: somite 6 with strong anal spine (fig. 6A); pleopods biramous, exopodites setose, first pair reduced.

Uropods: endopod with 35 marginal setae; exopod with 37 marginal setae and a strong outer spine (fig. 6A).

Telson: with concave medial-distal waist extending proximally; lateral margin bearing 4 reduced spines; posterior margin with small median indentation and $6+6$ processes (fig. 6A).

\section{DISCUSSION}

Biogeography. - About 250 decapod species have already been recorded from Chilean Pacific coastal waters (Retamal, 1981; Wehrtmann \& Báez, 1997), and new records do increase these numbers, especially in some rare groups (e.g., Thatje, 2000; Thatje \& Gerdes, 2000). These decapods include only two representatives of the Pandalidae, Austropandalus grayi (Cunningham, 1871) and Heterocarpus reedi Bahamonde, 1957 (Retamal, 1981; Gorny, 2000). The Chilean South Patagonian Icefield $\left(46^{\circ}-52^{\circ} \mathrm{S}\right)$ was shown to be restrictive for most of these species, due to extreme environmental conditions, e.g., mean lower temperatures 
that have often been described as being similar to those of Antarctica (compare: Sievers et al., 1996; Thatje \& Mutschke, 1999). A total of only eight decapod species was recorded for this region, with only one representative of the Caridea (Campylonotus semistriatus Bate, 1888; Mutschke et al., 1996).

Intensive investigations performed in the channels and fjords of the SubAntarctic Magellan region (e.g., Arntz \& Gorny, 1996), showed only Austropandalus grayi to occur there, making up about $66 \%$ of the caridean fauna, thus being an important part of the decapod fauna in general (Arntz et al., 1996; Wehrtmann \& Lardies, 1996; Gorny, 2000).

Three pandalid species have been recorded from the coastal waters of the southwestern Atlantic Ocean, from Uruguay southwards to the Argentinean coast of Tierra del Fuego (Spivak, 1997). A. grayi and Pandalopsis ampla are distributed in the area under investigation (Boschi, 1976; Boschi et al., 1992), whereas the southernmost occurrence of Pantomus parvulus A. Milne-Edwards, 1883, is recorded for Uruguay (Zolessi \& Philippi, 1995; Spivak, 1997). A. grayi is the most common and widely distributed of these species, as also shown by the larval records during our investigation (fig. 7). Pandalopsis ampla is a typical species of the continental slope of Patagonia and seems to be restricted to that area (see Boschi, 1973; Boschi et al., 1981).

Phylogenetic relationships. - Several morphological larval characteristics within the Pandalidae, which are more homogeneous than in the Hippolytidae (e.g., Wehrtmann \& Albornoz, 1998), divide this family into three principal groups:

1. Pandalina brevirostris (Rathke, 1843), Dichelopandalus bonnieri Caullery, 1896, and Pandalus montagui Leach, 1814 (cf. Pike \& Williamson, 1964), with a seta or terminal spine at the antennal endopodite, and an outer seta on the basipodite of the maxillule.

2. Pandalus jordani Rathbun, 1902 (cf. Rothlisberg, 1980) and Pandalus platyceros Brandt, 1851 (cf. Price \& Chew, 1972), with an apical seta at the antennal spine, but without outer seta on the basipodite of the maxillule.

3. Pandalus borealis Krøyer, 1838 (cf. Kurata, 1964) and Pandalus stenolepis Rathbun, 1902 (cf. Gurney, 1942; Pike \& Williamson, 1964), with a strong antennal spine, without apical seta, and with an outer seta on the basipodite of the maxillule.

Apart from these differences, pandalid larvae share several comparable morphological features, which ultimately confirm a level of homogeneity in this family:

- eye peduncle narrowed at base;

- antennular peduncles strongly concave, separated in-between;

- antennal exopodite segmented; 


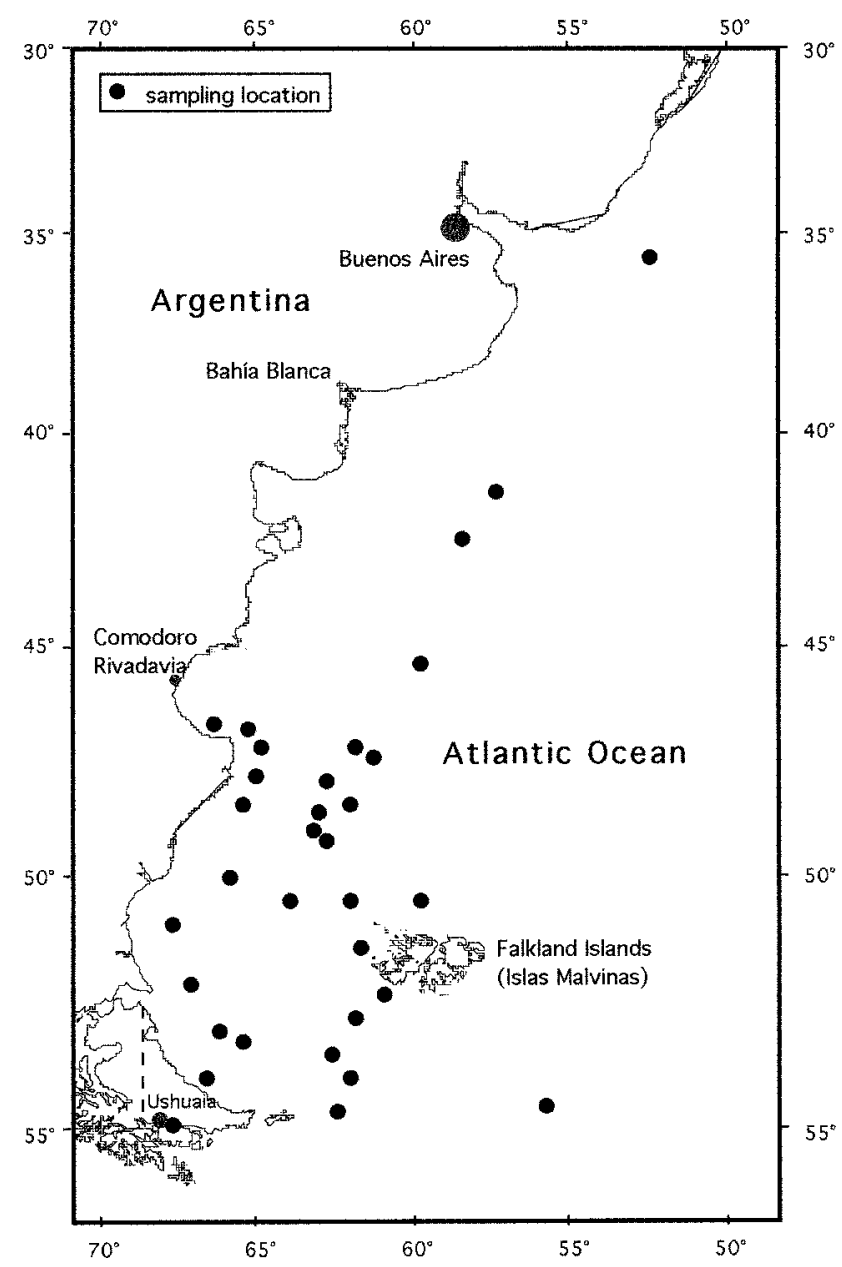

Fig. 7. Sampling locations of Austropandalus grayi (Cunningham, 1871) (zoeal stages I-V and advanced zoea) in the southwestern Atlantic Ocean.

- rostrum well-developed since first stage;

- supraorbital spines present;

- carapace with two dorsal protuberances.

Further descriptions and remarks of differences between pandalid genera are given by Berkeley (1930) to which we refer. Only one larval type with a feature corresponding to the family characteristics mentioned above, was distinguished from plankton samples obtained during our investigations. Larval characteristics are:

- rostrum well-developed since first stage;

- carapace with pterygostomian and supraorbital spines present, anteroventral margin with 3 spines; 
- peduncle of antennule strongly concave, separated at base;

- antenna with segmented exopodite in zoeal stages I-III, endopodite with 1 spine and a terminal seta in stages I+ II;

- maxilla with external seta;

- exopodites present in pereiopods 1 to 3 and chela of pereiopod 1 more reduced than in second pereiopod;

- abdominal somites without ornamentation and ventrolateral spines;

- anal spine present from zoea IV;

- telson strongly concave with not more than $6+6$ processes at posterior margin, the same in advanced stage.

The zoeae described herein belong to the Pandalidae, and were clearly identified to correspond to A. grayi, taking into account their morphology, biogeographical separation from other pandalid species of the Magellan Region and the southwestern Atlantic, as well as the comparison between reared 1st zoeae and plankton material. Larvae of A. grayi obviously show similarities to those of Pandalina brevirostris (compare with Pike \& Williamson, 1964). Though we were not able to compare larvae of A. grayi with that of the second pandalid species from the continental slope of Argentina, Pandalopsis ampla, we assume larvae of this species to be similar to that of Pandalopsis dispar Rathbun, 1902 (cf. Berkley, 1930) and $P$. coccinata Urita, 1941 (cf. Kurata, 1964), due to similarities in adult features. However, the big-sized eggs of $P$. ampla, which were studied by us, indicate the existence of an abbreviated planktonic larval development, as observed for the other species of this genus. Nevertheless, this theory needs to be checked in future investigations.

The larval development of $P$. coccinata finishes at a more advanced stage than in $P$. dispar, with $28+28$ and $12+12$ processes on the posterior margin of the telson, respectively. Additionally, thoracopodal exopods of the first species are more reduced and the pleopods are more developed than in the second one.

Based on larval characteristics, Pike \& Williamson (1964) grouped together all species whose larvae bear exopodites on the pereiopods 1 to 3 (viz., Pandalina, Oligocaris, Dichelopandalus, and some species of Pandalus, and, on the basis of our descriptions, also Austropandalus). Another group is represented by those larvae that bear exopodites on pereiopods 1 and 2 (viz., Pandalopsis, some species belonging to Pandalus). Due to the absence of the exopodite from the third maxilliped of adults, without associated change in size compared to the larval morphology, the genus Pandalus seems to be a derivative from Dichelopandalus. Possibly later, during the evolution of the other species of the genus Pandalus, some of those lost the exopodite of the third larval pereiopod, and others reduced the number of larval stages. In one group the modification of the first adult pereiopod apparently is the origin of the genus Pandalopsis. 


\section{ACKNOWLEDGEMENTS}

Thanks are due to Ingo Wehrtmann and an anonymous referee for their critical and helpful comments on the manuscript. The first author acknowledges the intensive support of his work in South America by the International Bureau of the German Ministry of Research (BMBF, project No. CHLC1a1a). We would like to thank Covadonga Orejas for correcting the Spanish abstract.

\section{REFERENCES}

Albornoz, L. \& I. S. Wehrtmann, 1997. Descripción y clave de los primeros estadíos larvales de camarones carídeos (Decapoda: Hippolytidae, Alpheidae, Rhynchocinetidae) de aguas costeras de Chile. Invest. mar., Valparaíso, 25: 121-133.

ArntZ, W. E. \& M. Gorny, 1996. Cruise report on the Joint Chilean-German-Italian Magellan "Victor Hensen" Campaign in 1994. Ber. Polarforsch., 190: 1-113.

Arntz, W. E., M. Gorny, I. Wehrtmann, M. Lardies \& R. Soto, 1996. Crustacea Decapoda: summary report. In: W. E. ARNTZ \& M. GORNY (eds.), Cruise report on the Joint Chilean-German-Italian Magellan "Victor Hensen" Campaign in 1994. Ber. Polarforsch., 190: 57-60.

Berkeley, A. A., 1930. The post-embryonic development of the common pandalids of British Columbia. Contrib. Canadian Biol. Fish., 6 (6): 79-114.

BosCHI, E. E., 1973. Aportes al conocimiento de tres especies de camarones de aguas profundas del Atlántico Sur (Crustacea, Caridea). Physis, Buenos Aires, (A) 32 (85): 233-244.

— - 1976. Nuevos aportes al conocimiento de la distribución geográfica de los Crustáceos Decápodos del Mar Argentino. Physis, Buenos Aires, (A) 35 (90): 59-68.

— —, 1981. Larvas de Crustacea Decapoda. In: D. B oltovskoy (ed.), Atlas de zooplancton del Atlántico Sudoccidental y métodos de trabajo con el zooplancton marino: 699-718. (Inst. Nac. Invest. Des. Pesq., Mar del Plata).

Boschi, E. E., C. E. Fischbach \& M. I. Iorio, 1992. Catálogo ilustrado de los crustáceos estomatópodos y decápodos marinos de Argentina. Frente marit., 10: 7-94.

Boschi, E. E. \& M. A. Scelzo, 1977. Desarrollo larval y cultivo del camarón comercial de Argentina Artemesia longinaris (Crustacea, Decapoda, Penaeidae). FAO, Informes de Pesca, 1 (159): 287-327.

Boschi, E. E., M. A. Scelzo \& B. Goldstein, 1967. Desarrollo larval de dos especies de crustáceos decápodos en laboratorio: Pachycheles haigae Rodrigues da Costa (Porcellanidae) y Chasmagnathus granulata Dana (Grapsidae). Bol. Inst. mar. (Mar del Plata), 12: 1-46.

Ciechoms Ki, J. D., M. D. Ehrlich, C. A. LAsta \& R. P. SAnCheZ, 1979. Campañas realizadas por el buque de investigación "Walther Herwig" en el Mar Argentino, desde mayo hasta noviembre 1978. Organización y reseña de datos básicos obtenidos. Contrib. Inst. Nac. Invest. Des. Pesq., Mar del Plata, 374: 1-311.

Cousseau, M. B., J. E. Hansen \& D. Gru, 1979. Campañas realizado por el buque de investigación "Shinkai Maru” en el Mar Argentino, desde abril de 1978 hasta abril de 1979. Organización y reseña de datos obtenidos. Contrib. Inst. nac. Invest. Des. Pesq., Mar del Plata, 373: $1-625$.

GoRnY, M., 2000. Biogeography and ecology of decapod crustaceans in the Southern Ocean. Scient. marina (in press).

GuRneY, R., 1937. Larvae of decapod Crustacea. Part IV. Hippolytidae. Discovery Rep., 14: 351404. 
— —, 1942. Larvae of decapod Crustacea: 1-306. (Ray Society, London).

HAYNES, E. B., 1978. Description of larvae of a hippolytid shrimp, Lebbeus groenlandicus, reared in situ in Kachemay Bay, Alaska. Fish. Bull., U.S., 76 (2): 457-465.

- - 1981. Early zoeal stages of Lebbeus polaris, Eualus suckleyi, E. fabricii, Spirontocaris arcuata, S. ochotensis, and Heptacarpus camtschaticus (Crustacea, Decapoda, Caridea, Hippolytidae) and morphological characterization of zoeae of Spirontocaris and related genera. Fish. Bull., U.S., 79 (3): 421-440.

- —, 1985. Morphological development, identification, and biology of larvae of Pandalidae, Hippolytidae, and Crangonidae (Crustacea, Decapoda) of the northern north Pacific Ocean. Fish. Bull., U.S., 83: 501-521.

Kurata, H., 1964. Larvae of decapod Crustacea of Hokkaido. 3. Pandalidae. Bull. Hokkaido reg. Fish. Res. Lab., 28: 23-50.

— - 1968. Larvae of Decapoda Anomura of Arasaki, Sagami Bay. II. Dardanus arrosor (Herbst) (Diogenidae). Bull. Tokai reg. Fish. Res. Lab., 56: 173-180.

LOVRICH, G. A., 2000. Seasonality of larvae of Brachyura and Anomura (Crustacea Decapoda) in the Beagle Channel, Argentina. Scient. marina (in press).

Mutschie, E., C. Rios, T. Hromic, M. Gorny, A. Montiel, M. Rauschert \& D. Gerdes,

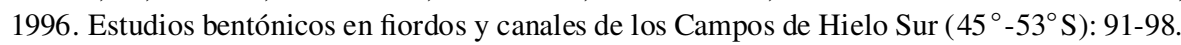
(Comite Oceanográfico Nacional Chile, Valparaíso).

Palma, G. S., 1994. Distribución y abundancia de larvas de langostino colorado (Pleuroncodes monodon ) frente a la costa de Concepción, Chile. Invest. mar., Valparaíso, 22: 13-29.

Pike, R. B. \& D. I. Williamson, 1964. The larvae of some species of Pandalidae (Decapoda). Crustaceana, 6: 265-284.

PRICE, V. A. \& K. K. CHEW, 1972. Laboratory rearing of spot shrimp larvae (Pandalus platyceros) and descriptions of stages. Journ. Fish. Res. Bd Canada, 29: 413-422.

RothlisberG, P. C., 1980. A complete larval description of Pandalus jordani Rathbun (Decapoda, Pandalidae) and its relation to other members of the genus Pandalus. Crustaceana, 38 (1): 1948.

Retamal, M. A., 1981. Catálogo ilustrado de los crustáceos decápodos de Chile. Gayana, (Zoología) 44: 1-110.

Scelzo, M. A. \& V. Lichtschein, 1978. Desarrollo larval y metamorfósis del cangrejo Cyrtograpsus altimanus Rathbun, 1914 (Brachyura, Grapsidae) en laboratorio, con observaciones sobre la ecología de la especie. Physis, Buenos Aires, (A) 38 (94): 103-126.

Schwabe, G. H., 1936. Investigaciones sobre Loxechinus albus Mol. y Pinnotheres chilensis Edw. Bol. Soc. Biol. Concepción, 19 (2): 125-136.

Sievers, H. A., J. L. Blanco \& A. Vega, 1996. Distribución de temperatura y salinidad en los fiordos y canales en el área del Crucero Cimar-Fiordo II: 17-20. (Comite Oceanográfico Nacional Chile, Valparaíso).

SpIVAK, E. D., 1997. Los crustáceos decápodos del Atlántico sudoccidental $\left(25^{\circ}-55^{\circ} \mathrm{S}\right)$ : distribución y ciclos de vida. Invest. mar., Valparaíso, 25: 73-92.

Thatje, S., 2000. Notiax santarita, a new species of the Callianassidae (Crustacea, Decapoda, Thalassinidea) from southernmost America. Crustaceana (in press).

Thatje, S. \& R. BACARdit, 2000. Larval stages of Chorismus tuberculatus (Bate, 1888) (Decapoda: Caridea: Hippolytidae), from the southwestern Atlantic Ocean. Journ. mar. biol. Assoc. U.K. (in press).

Thatje, S., R. Bacardit, M. C. Romero, F. Tapella \& G. A. Lovrich, in press. Description and key to the zoeal stages of the Campylonotidae (Decapoda, Caridea) from the Magellan Region. Journ. Crust. Biol.

Thatje, S. \& D. Gerdes, 2000. Upogebia australis, a new species of the Upogebiidae (Crustacea, Decapoda, Thalassinidea) from the Beagle Channel (southernmost America). Mitt. Mus. Naturkunde Berlin, (Zool.) (in press). 
Thatje, S. \& E. MutschKe, 1999. Distribution of abundance, biomass, production and productivity of macrozoobenthos in the Sub-Antarctic Magellan Province (South America). Polar Biol., 22 (1): 31-37.

Wehrtmann, I. S. \& L. Albornoz, 1998. Larval development of Nauticaris magellanica (A. Milne Edwards, 1891) (Decapoda: Caridea: Hippolytidae), reared under laboratory conditions. Bull. mar. Sci. Univ. Miami, 62 (1): 45-72.

Wehrtmann, I. S. \& P. BÁEZ, 1997. Larvas y estadíos tempranos de desarrollo de crustáceos decápodos de Chile: descripciones publicadas. Invest. mar., Valparaíso, 25: 263-276.

Wehrtmann, I. S. \& M. A. Lardies, 1996. Species composition and geographical distribution of caridean shrimps (Decapoda: Caridea). In: W. E. ARnTZ \& M. GornY (eds.), Cruise report on the Joint Chilean-German-Italian Magellan "Victor Hensen" Campaign in 1994. Ber. Polarforsch., 190: 63-67.

Williamson, D. I., 1960. Larval stages of Pasiphaea sivado and some other Pasiphaeidae (Decapoda). Crustaceana, 1 (4): 331-341.

— - 1968. Names of larvae in the Decapoda and Euphausiacea. Crustaceana, 16: 210-213.

— - 1982. Larval morphology and diversity. In: D. E. BLISS (ed.), The biology of Crustacea, 2: 43-110.

Zolessi, L. C. \& M. E. PhilipPI, 1995. Lista sistemática de decápoda del Uruguay (Arthropoda: Crustacea). Comunicaciones zoológicas, Mus. Hist. nat., Montevideo, 12 (183): 1-23. 